\title{
Neurochemical Alterations in Sudden Unexplained Perinatal Deaths-A Review
}

\author{
Nazeer Muhammad', Muhammad Sharif', Javeria Amin'1, Riffat Mehboob²,3, \\ Syed Amir Gilani ${ }^{2}$, Nargis Bibi ${ }^{1,4}$, Hasnain Javed ${ }^{5}$ and Naseer Ahmed ${ }^{2,6,7 *}$
}

${ }^{1}$ COMSATS Institute of Information Technology, Wah Cantonment, Pakistan, ${ }^{2}$ Research Unit, Faculty of Allied Health Sciences, University of Lahore, Lahore, Pakistan, ${ }^{3}$ University Institute of Physical Therapy, Faculty of Allied Health Sciences, University of Lahore, Lahore, Pakistan, ${ }^{4}$ Department of Computer Sciences, Fatima Jinnah Women University, Rawalpindi, Pakistan, ${ }^{5}$ Department of Microbiology and Molecular Genetics, University of the Punjab, Lahore, Pakistan, ${ }^{6}$ Medical School, University of Verona, Verona, Italy, ${ }^{7}$ Faculty of Health Sciences, University of the Punjab, Lahore, Pakistan

\section{OPEN ACCESS}

Edited by: Ilknur Aydin Avci,

Ondokuz Mayıs University, Turkey

Reviewed by:

Özge Öz,

Ondokuz Mayıs University, Turkey

Selda Rizalar,

Istanbul Medipol University, Turkey

Birsen Altay,

Ondokuz Mayıs University, Turkey

*Correspondence:

Naseer Ahmed dr.naseer99@gmail.com

Specialty section:

This article was submitted to

Child Health and Human

Development,

a section of the journal

Frontiers in Pediatrics

Received: 19 June 2017 Accepted: 09 January 2018 Published: 25 January 2018

Citation:

Muhammad N, Sharif M, Amin J, Mehboob R, Gilani SA, Bibi N, Javed $H$ and Ahmed N (2018) Neurochemical Alterations in

Sudden Unexplained Perinatal

Deaths $-A$ Review.

Front. Pediatr. 6:6.

doi: 10.3389/fped.2018.00006
Sudden unexpected perinatal collapse is a major trauma for the parents of victims. Sudden infant death syndrome (SIDS) is unexpected and mysterious death of an apparently healthy neonate from birth till 1 year of age without any known causes, even after thorough postmortem investigations. However, the incidence of sudden intrauterine unexplained death syndrome (SIUDS) is seven times higher as compared with SIDS. This observation is approximated $40-80 \%$. Stillbirth is defined as death of a fetus after 20th week of gestation or just before delivery at full term without a known reason. Pakistan has the highest burden of stillbirth in the world. This basis of SIDS, SIUDS, and stillbirths eludes specialists. The purpose of this study is to investigate factors behind failure in control of these unexplained deaths and how research may go ahead with improved prospects. Animal models and physiological data demonstrate that sleep, arousal, and cardiorespiratory malfunctioning are abnormal mechanisms in SIUDS risk factors or in newborn children who subsequently die from SIDS. This review focuses on insights in neuropathology and mechanisms of SIDS and SIUDS in terms of different receptors involved in this major perinatal demise. Several studies conducted in the past decade have confirmed neuropathological and neurochemical anomalies related to serotonin transporter, substance $P$, acetylcholine $\alpha 7$ nicotine receptors, etc., in sudden unexplained fetal and infant deaths. There is need to focus more on research in this area to unveil the major curtain to neuroprotection by underlying mechanisms leading to such deaths.

Keywords: sudden infant death, sudden perinatal death, stillbirth, neuropathology, sudden intrauterine death, neurochemicals

\section{INTRODUCTION}

In the first year of life, the most frequent type of death is "Crib death," "Cot death" commonly termed as "sudden infant death syndrome" (SIDS). Among every 1,700-2,000 births approximately, one baby gets affected (1). Numerous inherited abnormalities, such as morphological substrates for SIDS-sudden intrauterine unexplained death syndrome (SIUDS), were detected, mainly represented by variations of cardiac conduction system just like accessory pathway, abnormal resorptive degeneration, and hypoplasia/agenesis of the vital brainstem structures. The National 
Child Health Institute and Human Development has expressed that SIDS is a developmental issue and it takes its root from the fetal development (2). The neuropathological examination plays a significant role in the death investigation procedure. However, just some limited reviews have sufficiently analyzed the neurological substrates, albeit even subtle anomalies of the autonomic nervous system can measure the dysfunctions in the fundamental functions, prompting sudden and unexpected death $(3,4)$. In-depth examination results, performed at the University of Milan, Lino Rossi Research Center, have added to recognize the area and the nature of these anomalies, normally observed in both SIUDS and SIDS. External risk factors, for example, alcohol, maternal smoking, and drug abuse are identified to be the potential contributors of SIUDS and SIDS (5) while environmental pollution such as insecticides and pesticides has also been reported recently (6).

\section{SUDDEN INFANT DEATH SYNDROME}

In a number of these infants, the cerebrum portion that controls the arousal and breathing from sleep is not yet mature enough to work appropriately. Preterm births and intrauterine growth restrictions can cause repressed cognitive development and chronic infarctions. Low immunological development and postnatal sleeping positions are responsible for major respiratory distress. In this section, we have discussed the risk factors for

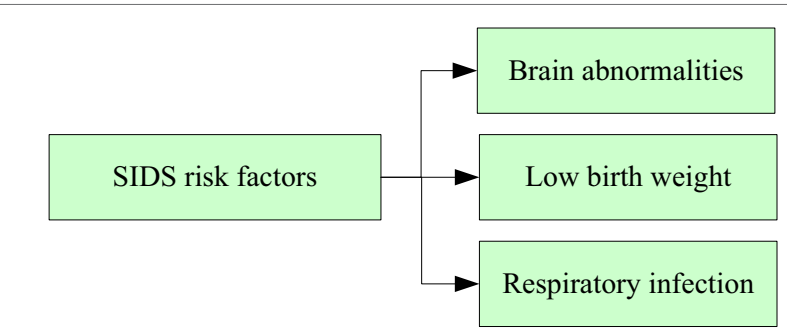

FIGURE 1 | Sudden infant death syndrome (SIDS) risk factors.
SIDS. Figure $\mathbf{1}$ is derived from Filiano and Kinney hypothesis (7) and shows risk factors contributing to SIDS.

\section{Neuropathology of SIDS}

The major focus on cerebrum anomalies in SIDS victims for a physiological investigation demonstrates cardiopulmonary abnormalities and sleep arousal dysfunction. A typical pathway of these abnormalities at the level of brainstem, where these control functions including ventilation pathways, cardiac rhythm, and pathways for sleep/arousal. Neuropathological basis of SIDS, as proposed to be the major risk factor and needs more neurochemical investigation (7). Research on the neurochemical abnormalities of SIDS victims was started in the 1980s (8). Some neurotransmitters and their functions in a normal infant or fetus are shown in Figure 2.

For instance, acetylcholine (ACh) and serotonin [5-hydroxytryptamines (5-HT)] were found to facilitate breathing (9) while epinephrine (Epi) and norepinephrine (NE) depressed breathing (10). Moreover, it was demonstrated that Epi, NE, and 5-HT were additionally required in the organization of sleep (11). Dopamine was observed to be required in stimulating breath while the peptide neuromodulator substance P (SP) $(12,13)$, endogenous opioids (14), and derived brain growth neurotrophic factor (BDNF) (15) were observed to be required in the focal control of breath. The neuropathology abnormalities identified in the SIDS brainstem (16) are summarized in Table 1.

\section{ACh Receptor}

Smoking in pregnancy fundamentally increases morbidity and perinatal mortality. It is presently the vital autonomous and modifiable risk factor adding to the sudden newborn child death disorder (SIDS) (27). The more convincing hypothesis for the connection among SIDS and smoking is that nicotine alters the vital breathing patterns and defensive reactions to hypoxia in sleeping (28). A lessened anxiety reaction intensifies hypoxia and apnea (29). The impacts of nicotine are interceded via its activation of very particular nicotinic cholinergic receptors (nAChRs) that are available in the carotid physiques and in

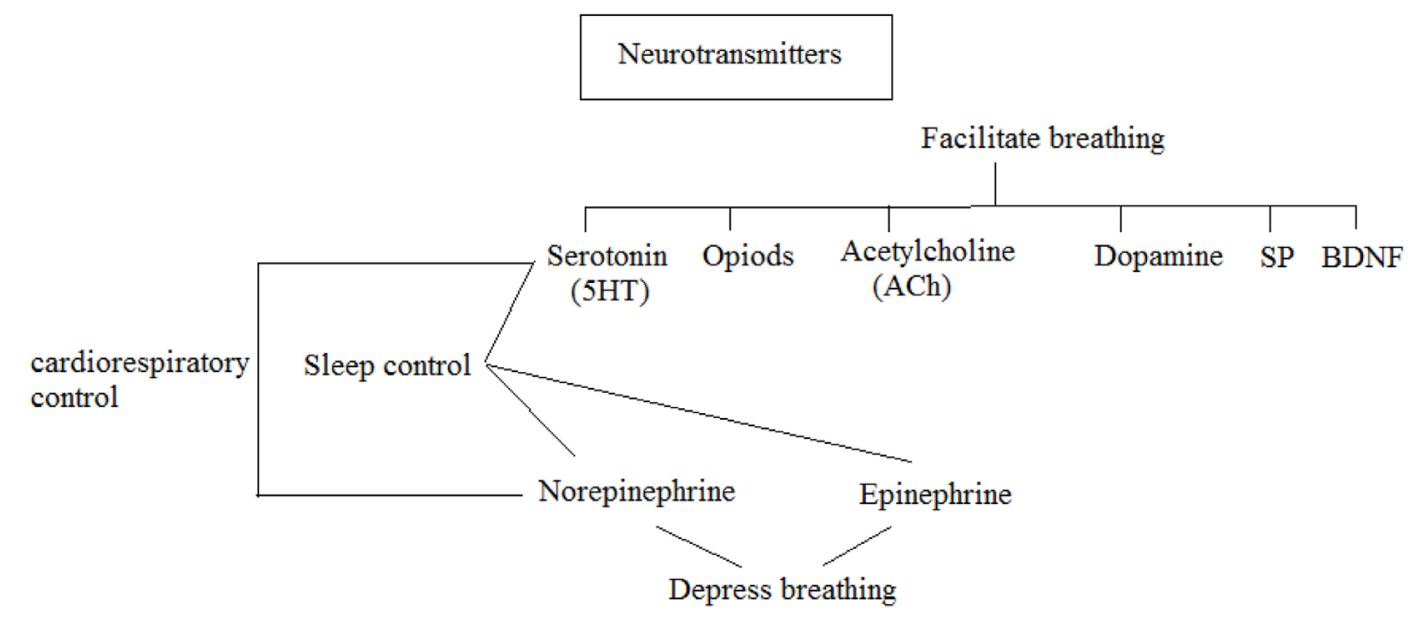

FIGURE 2 | Few neurotransmitters in normal fetus and infants. 
TABLE 1 | Summary for the identification of all neuropathology abnormalities in the sudden infant death syndrome (SIDS) brainstem.

\begin{tabular}{|c|c|c|c|c|}
\hline Reference & Enzyme, transmitter, or receptor & Level of brainstem & SIDS cases & Results \\
\hline$(17)$ & $\begin{array}{l}\text { An immunohistochemical method } \\
\text { involving tyrosine hydroxylase }\end{array}$ & $\begin{array}{l}\text { Diencephalon, basal ganglia, } \\
\text { midbrain, pons, and medulla } \\
\text { oblongata }\end{array}$ & 37 & $\begin{array}{l}\text { In SIDS, changes in basal ganglia can be induced via } \\
\text { repeated ischemia or chronic hypoxia but can be } \\
\text { associated with developing a neuronal system to the } \\
\text { upper cardiorespiratory control }\end{array}$ \\
\hline$(18)$ & $\begin{array}{l}\text { 5-Hydroxytryptamines }(5-\mathrm{HT}) \\
\text { and } 5 \text {-hydroxyindoleacetic acid }\end{array}$ & $\begin{array}{l}\text { High-performance liquid } \\
\text { chromatography and Raphe } \\
\text { obscure and PGCL }\end{array}$ & 35 & $\begin{array}{l}\text { SIDS was related with lower TPH } 2 \text { and } 5-\mathrm{HT} \text { levels, } \\
\text { consistent with a deficiency of medullary } 5 \text {-HT disorder }\end{array}$ \\
\hline$(13)$ & $\begin{array}{l}\text { Immunohistochemical expression } \\
\text { and substance P (SP) }\end{array}$ & Neuromodulator & 20 & SP localized in fiber structures, with low to high densities \\
\hline (19) & ${ }^{3} \mathrm{H}$-nicotine & 16 brainstem nuclei & 27 & $\begin{array}{l}\text { In the brainstem alcohol and smoking adversely affect } 3 \\
\mathrm{H} \text {-nicotinic binding }\end{array}$ \\
\hline$(20)$ & $\begin{array}{l}\alpha 7 \text { and } \beta 2 \text { Nicotinic acetylcholine } \\
\text { receptors (nAChRs) }\end{array}$ & Rostral medulla and pons & 46 & $\begin{array}{l}\text { SIDS infants have a genetic defect acquired in the } \\
\text { molecular regulation }\end{array}$ \\
\hline$(21)$ & $\gamma$-Aminobutyric acid & Medulla & 24 & $\begin{array}{l}\text { SIDS may essential to include therapeutic agents that } \\
\text { target more } \\
\text { than one neurotransmitter system }\end{array}$ \\
\hline$(22)$ & $1 \mathrm{~A}(5 \mathrm{HT} 1 \mathrm{AR})$ & Rostral medulla & 67 & $\begin{array}{l}\text { In SIDS cigarette smoke and prone sleeping exposure } \\
\text { support serotonergic brainstem system }\end{array}$ \\
\hline (23) & Serotonergic $(5-\mathrm{HT})$ & Respiratory nuclei and medulla & 16 & $\begin{array}{l}\text { An outcome demonstrates that increased neurochemical } \\
\text { preliminary evidence that supports boy's vulnerability to SIDS }\end{array}$ \\
\hline (24) & Interleukin-2 and cytokine & $\begin{array}{l}\text { Cardiorespiratory- and sleep/ } \\
\text { arousal pathophysiology }\end{array}$ & 18 & $\begin{array}{l}\text { The neuro-molecular disequilibrium results in the delicate } \\
\text { molecular balance producing dysfunction in brainstem } \\
\text { centers and disturbed homeostasis }\end{array}$ \\
\hline$(25)$ & Pro-BDNF, rh-BDNF, and TrkB & Rostral medulla & 67 & $\begin{array}{l}\text { In the brainstem provides abnormal expression of rh-BDNF, } \\
\text { TrkB, and pro-BDNF receptor protein of SIDS and non-SIDS } \\
\text { infants }\end{array}$ \\
\hline (26) & $\begin{array}{l}\text { Pontine Kolliker-Fuse nucleus } \\
\text { and orexin receptors }\end{array}$ & Raphe nuclei and locus coeruleus & 28 & KF neurons detection only $20 \%$ of SIDS \\
\hline
\end{tabular}

TABLE 2 | Summary for the identification acetylcholine receptor abnormalities in the sudden infant death syndrome brainstem.

\begin{tabular}{|c|c|c|c|}
\hline Reference & Receptor & Samples & Results \\
\hline (34) & nAChR & $\begin{array}{l}\text { Procedure of all animal from } \\
\text { National Institutes of Health Care }\end{array}$ & $\begin{array}{l}\text { Calcineurin activation and reduced intracellular calcium } \\
\text { by L-type channels }\end{array}$ \\
\hline (34) & $\begin{array}{l}\text { Neuronal nicotinic acetylcholine } \\
\text { receptors (nAChR), } \alpha_{7}, \beta_{2}\end{array}$ & Rats & $\begin{array}{l}\text { The existence of nicotine }(10 \mathrm{M}) \text { in hypoxic insult secured } \\
\text { a subpopulation }\end{array}$ \\
\hline (35) & $\begin{array}{l}\text { Nicotinic acetylcholine receptors, } \\
\beta_{2}{ }^{+/+} \text {mice }\end{array}$ & $\begin{array}{l}\text { Animals were used from the } \\
\text { National Research Center }\end{array}$ & Modulate $\beta_{2}-n A C h R s$ to the survival of infant brain cells \\
\hline (36) & $\begin{array}{l}\text { Nicotinic cholinergic receptor } \\
(\mathrm{nAChR})\end{array}$ & Feminine rats & $\begin{array}{l}\text { Reduced } n A C h R \text { expression in dopaminergic areas in the } \\
\text { duration of adolescence }\end{array}$ \\
\hline (31) & Nicotine impairs breathing & $\begin{array}{l}\text { Age-matched wild-mutant mice } \\
\text { deficient the subunit } \beta_{2} \mathrm{nAChR} \text { gene }\end{array}$ & $\begin{array}{l}\text { The nAChRs are vital in breathing in the duration of sleeping and } \\
\text { are important for the ordinary improvement in the mechanisms } \\
\text { of arousal }\end{array}$ \\
\hline (33) & Nicotine and preBotzinger complex & Medullary slice & $\begin{array}{l}\text { Nicotinic acetylcholine receptors (nAChRs) activation improved } \\
\text { the tonic synaptic excitatory input to inspiratory neurons }\end{array}$ \\
\hline$(37)$ & $\begin{array}{l}\text { Nicotinic acetylcholine receptors } \\
\text { (nAChRs) }\end{array}$ & $\begin{array}{l}\text { The animals used were an } \\
\text { adult male, age-matched }\end{array}$ & $\begin{array}{l}\text { nAChRs with } \beta_{2} \text { contribute activity in REMS, NREMS, and the } \\
\text { promoting effect of stress }\end{array}$ \\
\hline
\end{tabular}

the serious brainstem cores, for example, the core of single tract and locus coeruleus (30). At these locales, nAChRs add to the cholinergic adjustment of arousal and breathing. Interference with the nAChRs functions on the presumed basis of negative nicotine reactions (31). Disturbing equilibrium among arousal and ventilatory responses could intensify respiratory failure in sleeping duration. Postnatal exposure to smoke tobacco during early stages is related to increase in the number of sicknesses in repository, pulmonary impaired function, and SIDS events. It is additionally connected through reduced (32) cognitive 


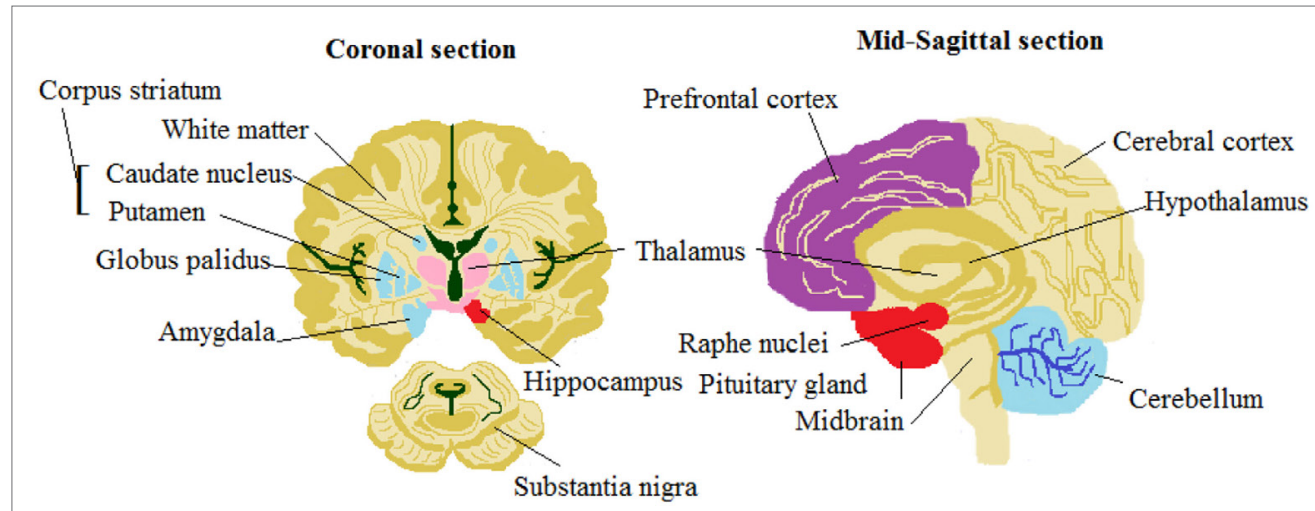

High 5-HTTA

Hippocampus

medical temporal cortex

Medium 5-HTTA

Pre-frontal cortex

Low-5HTTA
Cerebellum
Basal ganglia
(Caudate, putamen,
globus nuclei)

Low-5HTTA globus nuclei)

FIGURE 3 | Role of serotonin 5-hydroxytryptamines (5-HT) neurotransmitter.

TABLE 3 | Summary for the identification of serotonin 5-hydroxytryptamines (5-HT) neurotransmitter abnormalities in the sudden infant death syndrome.

\begin{tabular}{|c|c|c|c|c|}
\hline Reference & Year & Method & Sample & Results \\
\hline (42) & 2014 & $\begin{array}{l}\text { Tryptophan hydroxylase } 2 \\
\text { (TPH2), 5-HT }\end{array}$ & Group of mice & $\begin{array}{l}\mathrm{TPH}^{-/-} \text {mouse is a useful model in the new medications searches for } \\
\text { depression }\end{array}$ \\
\hline (43) & 2014 & $\begin{array}{l}\text { Serotonin }(5-\mathrm{HT}) \text { and } \\
\text { oxytocin (OXT) }\end{array}$ & 4 healthy males & $\begin{array}{l}\text { In the amygdala effects of OXT on 5-HT1A within the subgenual cortex } \\
\text { can be mediated via induced effects occurring of OXT }\end{array}$ \\
\hline (45) & 2017 & $5-\mathrm{HT}_{7}$ & Mice & $\begin{array}{l}5-\mathrm{HT}_{7} \text { brain receptor-ERK system performed a vital role in the adaptation } \\
\text { of stress formation }\end{array}$ \\
\hline (46) & 2017 & $5-\mathrm{HT}_{4} \mathrm{R}$ & $\begin{array}{l}24 \text { healthy participants } \\
\text { and } 3 \text { woman }\end{array}$ & $\begin{array}{l}\text { In the association's differences, } 5-\mathrm{HT}_{4} \mathrm{R} \text { binding between negative, } \\
\text { positive, and neutral word categories did not statistically reach }\end{array}$ \\
\hline (40) & 2014 & $\begin{array}{l}5-\mathrm{HT}_{1 \mathrm{~A}} \text { and } \mathrm{mRNA} \\
\text { expression }\end{array}$ & Adult rat & $\begin{array}{l}\text { Serotonin transporter mRNA reduction shows variants in polymorphic } \\
\text { individuals with depression at the higher risk }\end{array}$ \\
\hline
\end{tabular}

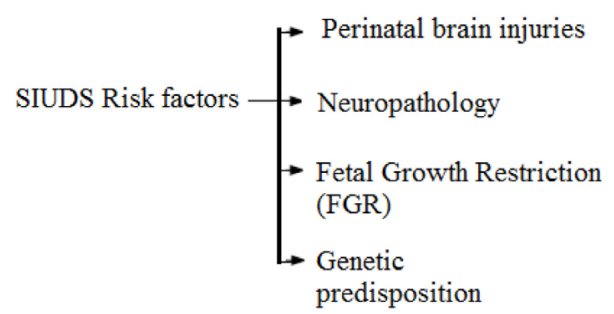

FIGURE 4 | Sudden intrauterine unexplained death syndrome (SIUDS) risk factors.

working and attention deficits in youth. Nicotine, the main neurotoxic segment of tobacco smoke, actuates its activities via binding to nicotinic acetylcholine receptors (nAChR). The immunohistochemical expression of nAChR subunits $\alpha_{2}, \alpha_{3}$, $\alpha_{4}, \alpha_{5}, \alpha_{7}, \alpha_{9}, \alpha_{1}$, and $\alpha_{2}$ in medulla brainstem was analyzed in a piglet model after postnatal nicotine exposure (33). Table 2 describes the ACh receptor abnormalities identified in the SIDS brainstem.

\section{Serotonin 5-HT Neurotransmitter}

In the brain development, serotonin 5-HT neurotransmitter performs a central role in stress reactivity, mood regulation disorders of psychiatric risk factors and subsequently signaling in 5-HT in the early stage have complicated implications on mental health and behavior over the life span. It takes part in the intercession of cognition, arousal, mood, cerebral blood flow and motor activity. It regulates cardiovascular and cardiorespiratory function, chemosensitivity, thermoregulation, arousal, and pain (38). Figure 3 shows the role of serotonin 5-HT. SIDS victims have been found to have reduced levels of brainstem serotonin (5-HT) and tryptophan hydroxylase 2 (TPH2) but retain producing 5-HT neurons. TPH2 is cerebrum particular enzyme that translates tryptophan into 5-HTP, which is then transformed over into 5-HT via DOPA decarboxylase.

Due to the disturbance in 5-HT medullary levels that outcomes in deadly dysfunction of these dependent sodium-pacemaker neurons regulated via projections of 5-HT from the Raphe and additional Raphe cores (39). We assumed that alteration might be brought about by contrasts in serotonin transporter mRNA expression and 5-HT1A receptor in mind regions included in the 
control of feelings, memory, and additionally in areas controlling the focal serotonergic tone (40). Table 3 summarizes all the serotonin 5-HT neurotransmitter abnormalities identified in the SIDS brainstem so far.

\section{Low Birthweight and Respiratory Tract Infection}

The sudden infant deaths are multifactorial, where low birthweight has been reported major risk factor for SIDS (47). Viral respiratory infections are mainly responsible for the occurrence of sudden death. Mild level of respiratory viral infection was observed by investigators in cases of sudden death infants up to $80 \%$ (48).

\section{SUDDEN INTRAUTERINE UNEXPLAINED DEATH SYNDROME}

Risk factors for SIUDS are shown in Figure 4. Perinatal brain injuries may occur due to trauma during pregnancy, birth asphyxia, and postnatal accident (48).

Fetal growth restriction (FGR) is a significant difficulty of pregnancy showing a fetus that does not develop to maximum capacity because of pathological compromise. FGR influences $3-9 \%$ of pregnancies in high-salary nations and is the main source of perinatal mortality. Placental insufficiency is the key reason for FGR, bringing about chronic fetal hypoxia. This initiates hypoxia of an adaptive fetal reaction of cardiovascular yield redistribution to support indispensable organs, involving the mind and is in result called cerebrum sparing. In spite of this, it is currently apparent that cerebrum sparing does not guarantee normal cerebrum growth in limited development fetuses (49). A brief summary of SIUDS is mentioned in Table 4.
Numerous neurodevelopmental issues of cognitive and motor function have their origins in the antenatal period. Fetal suboptimal growth is probably a key variable underlying altered cerebrum growth. FGR is related with perinatal death, preterm birth and, for survivors, an expanded risk of sensory and motor neurodevelopmental deficits, learning and cognitive impairments, and cerebral palsy. The implementation of the neuroprotective treatments can just happen in light of careful characterization of the abnormalities in brain growth that increases because of FGR, first require the identification of newborn children at most serious risk for the impairment of neurodevelopmental secondary to fetal poor development. Eighty pregnancies end up in termination following detection of an abnormal fetal, neonatal death, or stillbirth, describing no less than eight thousand cases per annum, and there are more than 500 unexplained baby and youth deaths every year. In these circumstances, the posthumous examination is frequently required to decide reason for death, set up implications for relatives, and direct administration of future pregnancies (55).

Fetal growth restriction is generally viewed as a risk for perinatal cerebrum injury with intraventricular hemorrhage (IVH), yet clinical reviews record altered outcomes with elevated, decreased, or unaltered rates of IVH in FGR newborn children contrasted with suitably developed counterparts. Placental insufficiency with anomalous umbilical artery Doppler was connected to the occurrence of IVH. While considering that cerebrum sparing is a characteristic reaction to placental chronic hypoxia, it is not amazing that changes in blood flow to the cerebrum might be both characteristics of the clinical seriousness of FGR, and related with impairments of neurodevelopment. The adaptive reaction of cerebrum sparing requires remodeling of the fetal cerebrum flow that can be diagnosed via Doppler ultrasound as a reduced pulsatility record in the cerebral arteries. At the point when a

TABLE 4 | Summary for the identification of abnormalities in the sudden intrauterine unexplained death syndrome.

\begin{tabular}{|c|c|c|c|c|}
\hline Reference & Year & Methods & Tested sample & Results \\
\hline$(50)$ & 2014 & Fetal growth restriction (FGR) & $\begin{array}{l}\text { Rats, guinea pigs, } \\
\text { rabbits, and sheep }\end{array}$ & $\begin{array}{l}\text { FGR is related with minimizing brain volume and altered structure, } \\
\text { cortical volume, and decreased total myelination that deficits } \\
\text { cells number }\end{array}$ \\
\hline$(51)$ & 2014 & $\begin{array}{l}\text { Magnetic resonance imaging (MRI), } \\
\text { corpus callosum, and intrauterine } \\
\text { growth-restricted (IUGR) fetuses }\end{array}$ & 173 IUGR fetuses & $\begin{array}{l}\text { Further explored corpus callosum to predict anomalous } \\
\text { neurodevelopment risk in pregnancies }\end{array}$ \\
\hline$(52)$ & 2014 & NRG1-IVNV & 41 cases & $\begin{array}{l}\text { Development of human neocortical provides expression } \\
\text { of quantitative NRG1 isoform }\end{array}$ \\
\hline (53) & 2017 & Cerebral palsy & Therapeutic candidates & Injury to developing the brain caused by the cerebral palsy \\
\hline$(54)$ & 2017 & Perinatal hypoxia & Humans and animals & In the FGR hypoxia is a vital problem in fetal-maternal medicine \\
\hline$(55)$ & 2017 & Human amnion epithelial cells (hAECs) & Mouse model & hAECs release trophic factors \\
\hline (56) & 2003 & $\begin{array}{l}\text { Diagnosis of IUGR, respiratory distress } \\
\text { syndrome, intraventricular hemorrhage, } \\
\text { and necrotizing enterocolitis }\end{array}$ & Newborn infants & $\begin{array}{l}\text { Increased IUGR with prematurity and represent a vital risk factor } \\
\text { in women when present with labor preterm }\end{array}$ \\
\hline$(57)$ & 2015 & $\begin{array}{l}\text { Ultrasound appearance of brain volume } \\
\text { and cortical development in fetuses }\end{array}$ & 20 fetuses & $\begin{array}{l}\text { Brain volume smaller in IUGR fetuses, with accelerated or normal } \\
\text { cortical maturation as depicted with the examination of postnatal } \\
\text { MRI, can be described by 3D prenatal ultrasound }\end{array}$ \\
\hline (58) & 2015 & $\mathrm{HbF}$ and BCL11A & 3 patients & $\begin{array}{l}\text { It highlights the significance of using hematopoietic-specific } \\
\text { methods when trying to target therapeutically BCL11A }\end{array}$ \\
\hline
\end{tabular}


vast cohort of children was isolated into weekly birth interims, it was found that rates of IVH in FGR were significantly lower versus non-FGR newborn children born at 28 weeks, proposing a defensive impact of development limitation, however, that IVH rates elevated significantly in late-FGR preterm births $>34$ weeks. This outcome has been confirmed by a recent review demonstrating that IVH was common in late-FGR preterm babies contrasted with suitably developed newborn children. That concern the finding of late preterm births, $>34$ and $<37$ weeks, represent most preterm births, and occurrence of preterm births is expanding $(59,60)$.

Sudden intrauterine unexplained death syndrome is multifactorial and polygenic condition. Although several genetic factors have been reported as cause of SIUDS but defining a specific genetic aberration at this stage is often a challenging issue due to limited phenotype-genotype correlation (61). In addition, genetic anomalies in under developed phenotypes are rarely investigated. Several studies have reported through whole genome sequencing the importance of neurodevelopmental and ion exchange pathway

\section{REFERENCES}

1. Ottaviani G. Defining sudden infant death and sudden intrauterine unexpected death syndromes with regard to anatomo-pathological examination. Front Pediatr (2016) 4:103. doi:10.3389/fped.2016.00103

2. Willinger M, James LS, Catz C. Defining the sudden infant death syndrome (SIDS): deliberations of an expert panel convened by the National Institute of Child Health and Human Development. Pediatr Pathol (1991) 11(5):677-84. doi:10.3109/15513819109065465

3. Rodriguez ML, McMillan K, Crandall LA, Minter ME, Grafe MR, Poduri A, et al. Hippocampal asymmetry and sudden unexpected death in infancy: a case report. Forensic Sci Med Pathol (2012) 8(4):441-6. doi:10.1007/ s12024-012-9367-5

4. Sparks DL, Hunsaker JC III. Neuropathology of sudden infant death (syndrome): literature review and evidence of a probable apoptotic degenerative cause. Childs Nerv Syst (2002) 18(11):568-92. doi:10.1007/s00381-002-0629-5

5. Pusiol T, Lavezzi A, Matturri L, Termopoli V, Cappiello A, Piscioli F, et al. Impact assessment of endocrine disruptors on sudden intrauterine and infant death syndromes. Eur J Forensic Sci (2016) 3(2):8/15. doi:10.5455/ejfs. 197968

6. Lavezzi AM, Cappiello A, Pusiol T, Corna MF, Termopoli V, Matturri L. Pesticide exposure during pregnancy, like nicotine, affects the brainstem alpha7 nicotinic acetylcholine receptor expression, increasing the risk of sudden unexplained perinatal death. J Neurol Sci (2015) 348(1-2):94-100. doi:10.1016/j.jns.2014.11.014

7. Filiano JJ, Kinney HC. A perspective on neuropathologic findings in victims of the sudden infant death syndrome: the triple-risk model. Biol Neonate (1994) 65(3-4):194-7. doi:10.1159/000244052

8. Myer EC, Morris DL, Adams ML, Brase DA, Dewey WL. Increased cerebrospinal fluid beta-endorphin immunoreactivity in infants with apnea and in siblings of victims of sudden infant death syndrome. J Pediatr (1987) 111(5):660-6. doi:10.1016/S0022-3476(87)80239-1

9. Millhorn DE, Eldridge FL, Waldrop TG. Prolonged stimulation of respiration by a new central neural mechanism. Respir Physiol (1980) 41(1):87-103. doi:10.1016/0034-5687(80)90025-0

10. Machaalani R, Waters KA. Neurochemical abnormalities in the brainstem of the sudden infant death syndrome (SIDS). Paediatr Respir Rev (2014) 15(4):293-300. doi:10.1016/j.prrv.2014.09.008

11. Masserano JM, King C. Effects on sleep of acetylcholine perfusion of the locus coeruleus of cats. Neuropharmacology (1982) 21(11):1163-7. doi:10.1016/0028-3908(82)90174-5

12. Mehboob R. Substance P/neurokinin 1 and trigeminal system: a possible link to the pathogenesis in sudden perinatal deaths. Front Neurol (2017) 8:82. doi:10.3389/fneur.2017.00082 genes (ARHGAP35, BBS7, CASZ1, COL2A1, CRIM1, DHCR7, HADHB, HAPLN3, HSPG2, MYO18B, RYR1, and SRGAP2).

\section{CONCLUSION}

A brainstem abnormality is suggested to be the main underlying etiological factor in SIUDS and SIDS victims. Alterations in certain neurotransmitters such as ACh receptor, serotonin 5-HT neurotransmitter, SP, and brain-derived neurotrophic growth factor (BDNF) are identified in the SIDS and SIUDS, which have vital roles in chemosensation and cardiorespiratory control leading to these sudden deaths. However, further studies are suggested to investigate more into this serious life threatening events.

\section{AUTHOR CONTRIBUTIONS}

All the authors have contributed equally in writing the manuscript.

13. Lavezzi AM, Mehboob R, Matturri L. Developmental alterations of the spinal trigeminal nucleus disclosed by substance $\mathrm{P}$ immunohistochemistry in fetal and infant sudden unexplained deaths. Neuropathology (2011) 31(4):405-13. doi:10.1111/j.1440-1789.2010.01190.x

14. Moss IR, Denavit-Saubié M, Eldridge FL, Gillis RA, Herkenham M, Lahiri S. Neuromodulators and transmitters in respiratory control. Fed Proc (1986) 45(7):2133-47.

15. EricksonJT, ConoverJC, Borday V, ChampagnatJ, Barbacid M, Yancopoulos G, et al. Mice lacking brain-derived neurotrophic factor exhibit visceral sensory neuron losses distinct from mice lacking NT4 and display a severe developmental deficit in control of breathing. J Neurosci (1996) 16(17):5361-71.

16. Mehboob R, Kabir M, Ahmed N, Ahmad FJ. Towards better understanding of the pathogenesis of neuronal respiratory network in sudden perinatal death. Front Neurol (2017) 8:320. doi:10.3389/fneur.2017.00320

17. Ozawa Y, Obonai T, Itoh M, Aoki Y, Funayama M, Takashima S. Catecholaminergic neurons in the diencephalon and basal ganglia of SIDS. Pediatr Neurol (1999) 21(1):471-5. doi:10.1016/S0887-8994(99)00033-8

18. Duncan JR, Paterson DS, Hoffman JM, Mokler DJ, Borenstein NS, Belliveau RA, et al. Brainstem serotonergic deficiency in sudden infant death syndrome. JAMA (2010) 303(5):430-7. doi:10.1001/jama.2010.45

19. Duncan JR, Randall LL, Belliveau RA, Trachtenberg FL, Randall B, Habbe D, et al. The effect of maternal smoking and drinking during pregnancy upon (3)H-nicotine receptor brainstem binding in infants dying of the sudden infant death syndrome: initial observations in a high risk population. Brain Pathol (2008) 18(1):21-31. doi:10.1111/j.17503639.2007.00093.x

20. Machaalani R, Say M, Waters KA. Effects of cigarette smoke exposure on nicotinic acetylcholine receptor subunits alpha7 and beta2 in the sudden infant death syndrome (SIDS) brainstem. Toxicol Appl Pharmacol (2011) 257(3):396-404. doi:10.1016/j.taap.2011.09.023

21. Broadbelt KG, Paterson DS, Belliveau RA, Trachtenberg FL, Haas EA, Stanley C, et al. Decreased GABAA receptor binding in the medullary serotonergic system in the sudden infant death syndrome. J Neuropathol Exp Neurol (2011) 70(9):799-810. doi:10.1097/NEN.0b013e31822c09bc

22. Machaalani R, Say M, Waters KA. Serotoninergic receptor $1 \mathrm{~A}$ in the sudden infant death syndrome brainstem medulla and associations with clinical risk factors. Acta Neuropathol (2009) 117(3):257-65. doi:10.1007/ s00401-008-0468-x

23. Paterson DS, Trachtenberg FL, Thompson EG, Belliveau RA, Beggs AH, Darnall R, et al. Multiple serotonergic brainstem abnormalities in sudden infant death syndrome. JAMA (2006) 296(17):2124-32. doi:10.1001/jama. 296.17.2124 
24. Kadhim H, Deltenre P, De Prez C, Sébire G. Interleukin-2 as a neuromodulator possibly implicated in the physiopathology of sudden infant death syndrome. Neurosci Lett (2010) 480(2):122-6. doi:10.1016/j.neulet. 2010.06.021

25. Tang S, Machaalani R, Waters KA. Expression of brain-derived neurotrophic factor and TrkB receptor in the sudden infant death syndrome brainstem. Respir Physiol Neurobiol (2012) 180(1):25-33. doi:10.1016/j.resp. 2011.10.004

26. Lavezzi AM, Ferrero S, Roncati L, Matturri L, Pusiol T. Impaired orexin receptor expression in the Kolliker-Fuse nucleus in sudden infant death syndrome: possible involvement of this nucleus in arousal pathophysiology. Neurol Res (2016) 38(8):706-16. doi:10.1080/01616412.2016.1201632

27. Alm B, Milerad J, Wennergren G, Skjaerven R, Oyen N, Norvenius G, et al. A case-control study of smoking and sudden infant death syndrome in the Scandinavian countries, 1992 to 1995. The Nordic Epidemiological SIDS study. Arch Dis Child (1998) 78(4):329-34. doi:10.1136/adc.78.4.329

28. Lavezzi AM, Ferrero S, Roncati L, Piscioli F, Matturri L, Pusiol T. Nicotinic receptor abnormalities in the cerebellar cortex of sudden unexplained fetal and infant death victims-possible correlation with maternal smoking. ASN Neuro (2017) 9(4):1759091417720582. doi:10.1177/1759091417720582

29. Holgert H, Hökfelt T, Hertzberg T, Lagercrantz H. Functional and developmental studies of the peripheral arterial chemoreceptors in rat: effects of nicotine and possible relation to sudden infant death syndrome. Proc Natl Acad Sci U S A (1995) 92(16):7575-9. doi:10.1073/pnas.92.16.7575

30. Lavezzi AM, Alfonsi G, Matturri L. Pathophysiology of the human locus coeruleus complex in fetal/neonatal sudden unexplained death. Neurol Res (2013) 35(1):44-53. doi:10.1179/1743132812Y.0000000108

31. Cohen G, Han ZY, Grailhe R, Gallego J, Gaultier C, Changeux JP, et al. beta 2 nicotinic acetylcholine receptor subunit modulates protective responses to stress: a receptor basis for sleep-disordered breathing after nicotine exposure. Proc Natl Acad Sci U S A (2002) 99(20):13272-7. doi:10.1073/pnas.192463599

32. Andrew H, Leyan X, Masayoshi N, Heather V, Ayon N, Hiroto K, et al. Increased [18F]ASEM $\alpha 7-\mathrm{nAChR}$ binding in diffuse traumatic brain injury (TBI) is opposite to that in the focal TBI in rodent models. J Nucl Med (2016) 57(2):347.

33. Shao XM, Feldman JL. Mechanisms underlying regulation of respiratory pattern by nicotine in preBotzinger complex. J Neurophysiol (2001) 85(6):2461-7. doi:10.1152/jn.2001.85.6.2461

34. Hejmadi MV, Dajas-Bailador F, Barns SM, Jones B, Wonnacott S. Neuroprotection by nicotine against hypoxia-induced apoptosis in cortical cultures involves activation of multiple nicotinic acetylcholine receptor subtypes. Mol Cell Neurosci (2003) 24(3):779-86. doi:10.1016/S1044-7431(03) 00244-6

35. Mechawar N, Saghatelyan A, Grailhe R, Scoriels L, Gheusi G, Gabellec MM, et al. Nicotinic receptors regulate the survival of newborn neurons in the adult olfactory bulb. Proc Natl Acad Sci U S A (2004) 101(26):9822-6. doi:10.1073/ pnas.0403361101

36. Zou D, Luo M, Han Z, Zhan L, Zhu W, Kang S, et al. Activation of alpha-7 nicotinic acetylcholine receptor reduces brain edema in mice with ischemic stroke and bone fracture. Mol Neurobiol (2016) 54(10):8278-86. doi:10.1007/ s12035-016-0310-8

37. Léna C, Popa D, Grailhe R, Escourrou P, Changeux JP, Adrien J. Beta2containing nicotinic receptors contribute to the organization of sleep and regulate putative micro-arousals in mice. J Neurosci (2004) 24(25):5711-8. doi:10.1523/JNEUROSCI.3882-03.2004

38. Brummelte S, Mc Glanaghy E, Bonnin A, Oberlander TF. Developmental changes in serotonin signaling: implications for early brain function, behavior and adaptation. Neuroscience (2017) 342:212-31. doi:10.1016/j. neuroscience.2016.02.037

39. Pena F, Ramirez JM. Endogenous activation of serotonin-2A receptors is required for respiratory rhythm generation in vitro. JNeurosci (2002) 22(24):11055-64.

40. Bravo JA, Dinan TG, Cryan JF. Early-life stress induces persistent alterations in 5-HT1A receptor and serotonin transporter mRNA expression in the adult rat brain. Front Mol Neurosci (2014) 7:24. doi:10.3389/fnmol.2014.00024

41. Popova NK, Kulikov AV, Kondaurova EM, Tsybko AS, Kulikova EA, Krasnov IB, et al. Risk neurogenes for long-term spaceflight: dopamine and serotonin brain system. Mol Neurobiol (2015) 51(3):1443-51. doi:10.1007/ s12035-014-8821-7
42. Sampson TR, Mazmanian SK. Control of brain development, function, and behavior by the microbiome. Cell Host Microbe (2015) 17(5):565-76. doi:10.1016/j.chom.2015.04.011

43. Mottolese R, Redouté J, Costes N, Le Bars D, Sirigu A. Switching brain serotonin with oxytocin. Proc Natl Acad Sci U S A (2014) 111(23):8637-42. doi:10.1073/pnas.1319810111

44. Haduch A, Bromek E, Kot M, Kamińska K, Gołembiowska K, Daniel WA. The cytochrome P450 2D-mediated formation of serotonin from 5-methoxytryptamine in the brain in vivo: a microdialysis study. J Neurochem (2015) 133(1):83-92. doi:10.1111/jnc.13031

45. Takeda K. Involvement of brain 5-HT 7 receptors in the formation of stress adaptation in mice. J Explor Res Pharmacol (2017) 2(1):1/23. doi:10.14218/ JERP.2016.00035

46. Stenbaek DS, Fisher PM, Ozenne B, Andersen E, Hjordt LV, McMahon B, et al. Brain serotonin 4 receptor binding is inversely associated with verbal memory recall. Brain Behav (2017) 7(4):e00674. doi:10.1002/brb3.674

47. Grether JK, Schulman J. Sudden infant death syndrome and birth weight. J Pediatr (1989) 114(4 Pt 1):561-7. doi:10.1016/S0022-3476(89)80694-8

48. Athanasakis E, Karavasiliadou S, Styliadis I. The factors contributing to the risk of sudden infant death syndrome. Hippokratia (2011) 15(2):127-31.

49. Murray E, Fernandes M, Fazel M, Kennedy SH, Villar J, Stein A. Differential effect of intrauterine growth restriction on childhood neurodevelopment: asystematicreview.BJOG(2015) 122(8):1062-72.doi:10.1111/1471-0528.13435

50. Miller SL, Yawno T, Alers NO, Castillo-Melendez M, Supramaniam VG, VanZyl N, et al. Antenatal antioxidant treatment with melatonin to decrease newborn neurodevelopmental deficits and brain injury caused by fetal growth restriction. J Pineal Res (2014) 56(3):283-94. doi:10.1111/jpi.12121

51. Egaña-Ugrinovic G, Sanz-Cortés M, Couve-Pérez C, Figueras F, Gratacós E. Corpus callosum differences assessed by fetal MRI in late-onset intrauterine growth restriction and its association with neurobehavior. Prenat Diagn (2014) 34(9):843-9. doi:10.1002/pd.4381

52. Paterson C, Wang Y, Kleinman JE, Law AJ. Effects of schizophrenia risk variation in the NRG1 gene on NRG1-IV splicing during fetal and early postnatal human neocortical development. Am J Psychiatry (2014) 171(9):979-89. doi:10.1176/appi.ajp.2014.13111518

53. Courtney A, McDonald MCM, Tayla RP, Graham J, Suzanne LM. Umbilical Cord Blood Cells for Perinatal Brain Injury: The Right Cells at the Right Time? Maurício AC, editor. Umbilical Cord Blood Banking for Clinical Application and Regenerative Medicine (2017). Available from: https://www.intechopen.com/books/umbilical-cord-blood-bankingfor-clinical-application-and-regenerative-medicine/umbilical-cord-bloodcells-for-perinatal-brain-injury-the-right-cells-at-the-right-time-

54. Paola C, Emilio AH, Bernardo JK. Epigenetic Programming of Cardiovascular Disease by Perinatal Hypoxia and Fetal Growth Restriction, Hypoxia and Human Diseases. Zheng J, editor. (2017). Available from: https://www.intechopen. com/books/hypoxia-and-human-diseases/epigenetic-programming-ofcardiovascular-disease-by-perinatal-hypoxia-and-fetal-growth-restriction

55. Leaw B, Zhu D, Tan J, Muljadi R, Saad MI, Mockler JC, et al. Human amnion epithelial cells rescue cell death via immunomodulation of microglia in a mouse model of perinatal brain injury. Stem Cell Res Ther (2017) 8(1):46. doi:10.1186/s13287-017-0496-3

56. Gilbert WM, Danielsen B. Pregnancy outcomes associated with intrauterine growth restriction. Am J Obstet Gynecol (2003) 188(6):1596-9; discussion 1599-601. doi:10.1067/mob.2003.384

57. Blair EM, Nelson KB. Fetal growth restriction and risk of cerebral palsy in singletons born after at least 35 weeks' gestation. Am J Obstet Gynecol (2015) 212(4):520.e1-7. doi:10.1016/j.ajog.2014.10.1103

58. Basak A, Hancarova M, Ulirsch JC, Balci TB, Trkova M, Pelisek M, et al. BCL11A deletions result in fetal hemoglobin persistence and neurodevelopmental alterations. J Clin Invest (2015) 125(6):2363-8. doi:10.1172/ JCI81163

59. Doğer E, Özdamar Ö, Çakıroğlu Y, Ceylan Y, Çakır Ö, Anık Y, et al. The predictive value of lactate peak detected by the magnetic resonance spectroscopy in the brain of growth-restricted fetuses for adverse perinatal outcomes. J Matern Fetal Neonatal Med (2016) 29(19):3178-82. doi:10.3109/14767058. 2015.1118040

60. Lewis AJ, Austin E, Galbally M. Prenatal maternal mental health and fetal growth restriction: a systematic review. J Dev Orig Health Dis (2016) 7(4):416-28. doi:10.1017/S2040174416000076 
61. Roncati L, Pusiol T, Piscioli F, Barbolini G, Maiorana A, Lavezzi A. The first 5-year-long survey on intrauterine unexplained sudden deaths from the northeast Italy. Fetal Pediatr Pathol (2016) 35(5):315-26. doi:10.1080/15513815. 2016.1185751

Conflict of Interest Statement: The authors declare that the research was conducted in the absence of any commercial or financial relationships that could be construed as a potential conflict of interest.
The reviewers BA and ÖÖ and the handling editor declared their shared affiliation.

Copyright () 2018 Muhammad, Sharif, Amin, Mehboob, Gilani, Bibi, Javed and Ahmed. This is an open-access article distributed under the terms of the Creative Commons Attribution License (CC BY). The use, distribution or reproduction in other forums is permitted, provided the original author(s) or licensor are credited and that the original publication in this journal is cited, in accordance with accepted academic practice. No use, distribution or reproduction is permitted which does not comply with these terms. 